\title{
THE SUBURBAN BATHS IN POMPEII: INNOVATIVE STRATEGIES OF CONSERVATION AND DIGITAL HUMANITIES FOR AN IMPROVED USE AND PERCEPTION
}

\author{
R. Picone ${ }^{1, *}$, L. Cappelli ${ }^{1}$ \\ ${ }^{1}$ Department of Architecture, University of Naples Federico II - (renata.picone, luigi.cappelli)@unina.it
}

Commission II - WG II/8

KEY WORDS: Pompeii, Conservation, Suburban Baths, Archaeological heritage, Digital humanities, Improvement of fruition

\begin{abstract}
:
The paper aims to examine the results of an experimental research on the enlarged fruition and "communication" of Pompeii archeological heritage. The main focus of the research were the Suburban Thermal baths in Pompeii, the ancient Roman city buried during the Vesiuvus volcano eruption in 79 a.C. The Suburban Thermal baths are located within the Insula Occidentalis, a wide area at West of the old city of Pompeii. They have been a special entrance to the archeological site since the rediscovery of the ancient city. The Thermal baths area was neglected for a long time, but then it was included in the conservation project for Porta Marina and the superintendence offices, led by Amedeo Maiuri. However, these measures didn't lead to in-depth, systematic studies, that were to be conducted only during the early '2000. Nowadays, new technologies can be helpful to convey the actual value of the big archeological heritage. In fact, they represent a real asset to show any transformation or restoration work, that made the thermal baths a peculiar, stratified artefact. The historical and artistic information have been reinterpreted in a more technological, contemporary language; therefore, the visitor has the opportunity to experience a more conscious and multilayer reading of the Pompeii thermal complex. In addition, in this paper will be examined new opportunities of collection, analysis and information sharing of the case study. A special focus will vert on how the conscious use of new technologies and storytelling may be the key to understand the material and immaterial traces of the Suburban Thermal baths.
\end{abstract}

\section{INTRODUCTION}

This paper aims to present the results of an interdisciplinary research, concerning with the broader fruition of the Suburban Thermal Baths in Pompeii (Figure 1). The research represents the final stage of a long path, started in 2010 by the "Federico II" University in the archeological area of Pompeii. Over the years, the researchers have studied operational criteria to make the entire archeological site accessible. At first, they focused on the reconfiguration and enhancement of the Insula Occidentalis. Then, they concentrated on the Suburban Thermal Baths and elaborated the project for an improved fruition. This multidisciplinary, multi-scale study was supported by a large number of teachers and scholars of architectural restoration, design, interior design, statistic, lighting and computer science.
First and foremost, the researchers focused on the urban space. After a preliminary tour in the area of Insula Occidentalis, they made a second, more conscious visit of the area and identified its archeological emergencies. Furthermore, a deep analysis of the context allowed to choose the strategies to guide the visitor from the ticket office to the Thermal Baths. The researchers did not consider Pompeii as a sum of archeological evidences, but as a living city. They understood that the tourist paths are crucial for a complete fruition and used them as an asset to handle such a complex system. The researchers operated through layers and modules and designed naturalistic paths, non-invasive technological devices, linear coverings, information systems, computer and virtual reality technologies applied to the small, but important, archeological evidence like Suburban Thermal Baths.

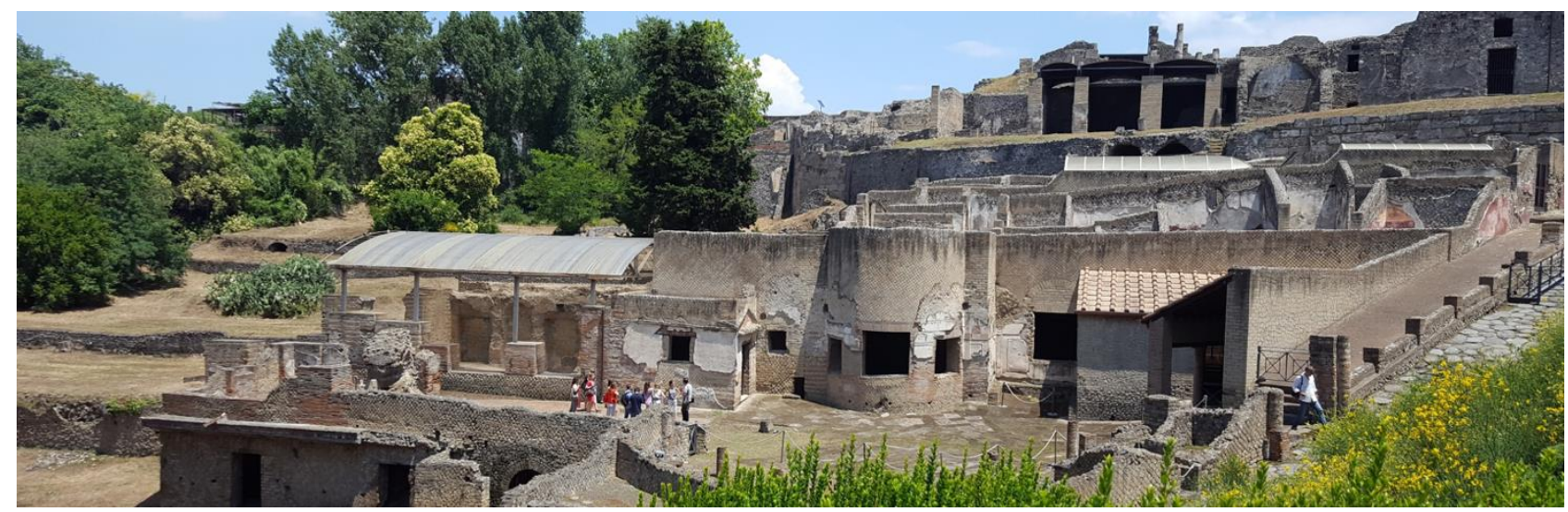

Figure 1. The Suburban Thermal Baths in Pompeii. Current use of the archeological site; it is necessary to improve its fruition. (ph: S. Borea, 2016).

\footnotetext{
* Corresponding author
} 


\section{FROM THE INSULA OCCIDENTALIS TO THE SUBURBAN BATHS: CONSERVATION AND EXPERIMENTATION}

The Suburban Thermal Baths are located within the Insula Occidentalis, a significant place and a scenery of many experimentations. The Insula Occidentalis has been a privileged area since the rediscovery of the buried city, and it was one of the first archeological areas to be excavated during the Bourbonic era. The suburban villas were built here; they were designed on multiple levels and their architectural plants were rather different from the plants of the domus. In the Insula there are big heaps of earth, called "Bourbonic piles", originated from the reversion of rubble and excavated materials. Since the XVIII century, these piles have been cluttering the entire area, hiding the original conformation of the Insula. Such alteration of the original orography and practicability of the suburban Pompeian area represents a real challenge. It is necessary to redraw the touristic paths and to solve the fruition criticality. (Figure 2).

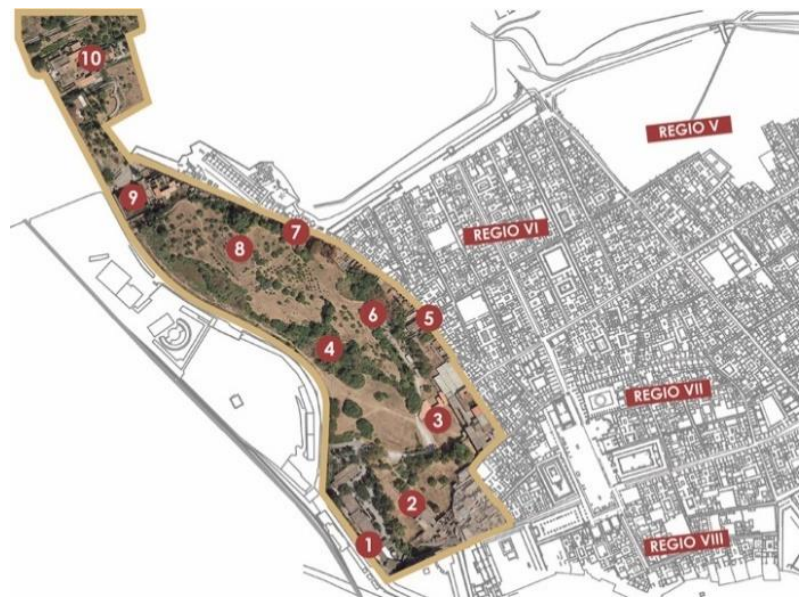

Figure 2. Framework of the Insula Occidentalis in the archeological area of Pompeii: 1. Superintendence offices and entrance of Porta Marina; 2. Suburban Thermal Baths; 3. Casa del bracciale d'oro and a «rest area»; 4. Bourbonic piles; 5. Palazzina Fiorelli; 6. «wood»; 7. Tomba di Mamia; 8. Villa di Cicerone; 9. Villa di Diomede; 10. Villa dei Misteri. (Designed by L. Cappelli).

The Thermal Baths are the crossroads of the Insula Occidentalis and the ancient via Marina, and they are connected with the current entrance of Porta Marina. Today this entrance is one of the most used access of the entire archeological site and it is used by all the tourists, arriving in Pompeii with the Circumvesuviana railroad.

The suburban area was the first part of Pompeii to be excavated in XVIII century. Later on, the excavation continued towards East from the suburban area, leaving the Thermal Baths in state of neglect for decades.

At last, they were included in the project of restoration of Porta Marina by the superintendent Amedeo Maiuri who was supported by the funding provided by the Cassa del Mezzogiorno (Maiuri, 1951). However, these measures did not lead to in-depth, systematic studies, that were to be conducted only during the early ' $2000{ }^{1}$.

Pompei was built in a strategical area, cleverly identified by the Romans. For one thing, this area has an easy access to the sea, whose coasts used to reach the present Circumvesuviana railroad line (Pappalardo, Grimaldi, 2001).

\footnotetext{
1 The work of M. Aoyogi U. Pappalardo, Pompei Insula Occidentalis, Napoli-
} Tokyo 2006 opened a fruitful series of studies and publications, concerning the
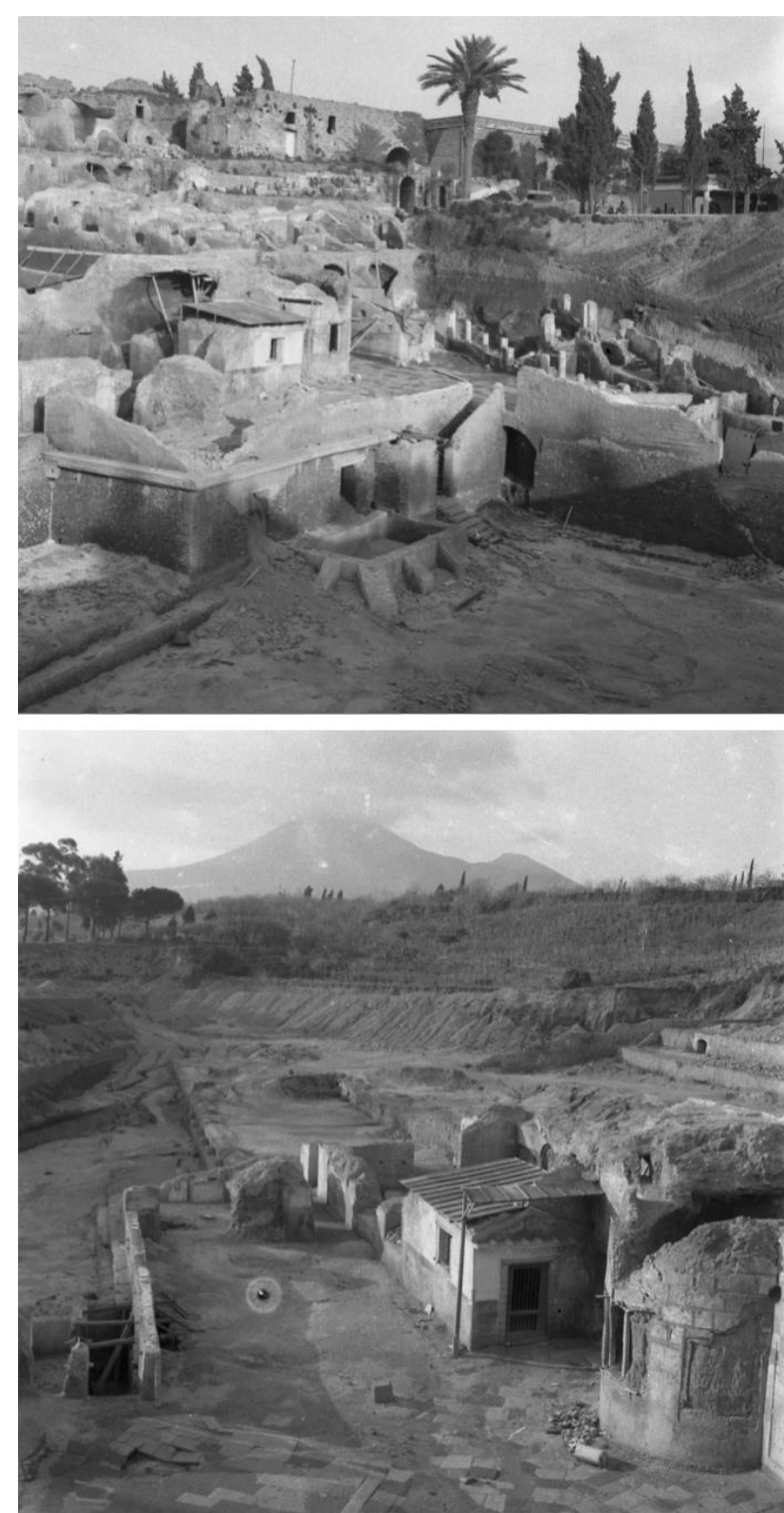

Figures 3 and 4. The funding of Progetto-Pompeii was divided in two parts. The first one, related to the Fio- 83 funds, allowed the restoration of the Thermal Baths (archive photos: ASAP D 24708, D 7896).

Moreover, this area is perched on strategic height. Not only these orographic conditions turned out to be providential from a defensive point of view, but they also allowed to build majestic, sumptuous villas, that sometimes were up to three floors high (Borea, 2017) and had a beautiful view on the sea.

These operations required the realization of bold terraces, audacious stabilization and ground levelling solutions, still visible today. The Thermal Baths were built on one of these terraces during the first century. The ideal position and the landscape resources (Jacobelli, 2001) allowed the Thermal Baths to attract and host a large number of visitors, both those entering and leaving the city. However, in time, this privileged position exposed the Thermal Baths to continuous spoliation.

urban development of the area, studied from an archeological, architectonic and artistic perspective. 
The restoration and enhancement project of the western Pompeian suburb (Grimaldi, 2015) also included the complex of the Suburban Thermal Baths. The latter are open to visitors since 1988, (Figures 3 and 4) thanks to the funding of ProgettoPompeii (De Simone, 1990). Today the Thermal Baths represent an interesting and complex system of architectural volumes, lay down on terraces. They are characterized by lavish frescoes and by touristic paths. The project for an improved fruition of the Thermal Baths requires a thorough knowledge of this kind of manufacts. Additionally, those in Pompeii are one of the few Thermal Baths with volts, frescoes and decorated rooms, that allow a cathartic perception of the whole space.

Entering the archeological site through the doorway of Porta Marina and seeing the Thermal Baths, the visitors have a first perception of the antiquity, enviable both from a naturalistic and archeological point of view. This access was built in 1980 and was conceived as a connecting point of several touristic paths of the archeological area. For this reason, it was provided by a series of high-altitude paths, stairs and differences of height, that recently are creating several problems to the wider accessibility (Figure 5).

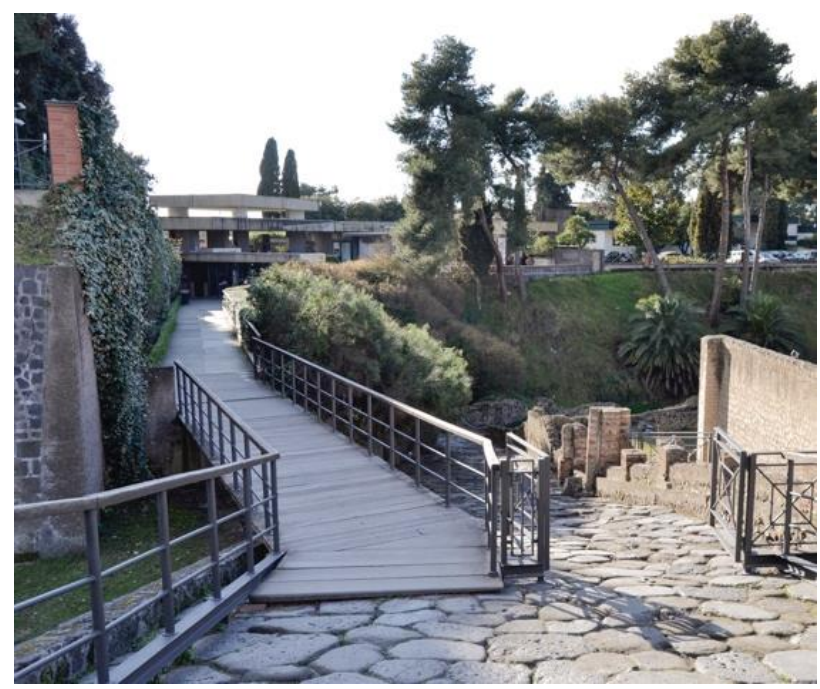

Figure 5. The wooden walkway "crosses" the Thermal Baths.

The 1980 itinerary can no longer be used, due to its lack of accessibility (ph: L. Cappelli, 2017).

By the main entrance, a wooden walkway merges onto the ancient via Marina and leads the visitors to the rests of the ancient city. This kind of layout make sure that the Thermal Baths remains on the edge on the intra-moenia archeological fabric.

The downhill access, placed along via Marina, is characterized by a floor made of an irregular, slippery paved road, by the presence of stairs that leads to the ancient vestibules at the entrance of the roman Baths and by the presence of a series of wooden walkways and carpets. All these features do not allow an easy fruition of the ancient complex of the roman building, especially to the visitors with physical disabilities.

The area surrounding the Suburban Baths is rather difficult. In fact, it is characterized by a series of terraces, significant differences in altitude and it slopes down to a cliff, which once was probably used as a dock. The areas close to the Thermal Baths have neither an orientation system nor directional signage. This area has not identified paths and there are several problems, connected to the rugged vegetation, which represent an obstacle for the perception and fruition of the entire archeological complex.
It is necessary to find some solutions to improve the accessibility and the fruition of the area and to preserve the archeological evidences. Similarly, it is important to create a touristic path, that could be both a cultural and a learning experience and that could involve all the visitors, including those with physical disabilities.

\section{THE SUBURBAN BATHS IN POMPEII: IMPROVED USE AND PERCEPTION}

The archeological site in Pompeii is characterized by difficult viability and it is still partially inaccessible to different kinds of visitors. However, the site offers an uncommon and exciting opportunity to study and create new solutions for the accessibility and fruition's issues of the archeological areas. Indeed, this site represents one of the most inaccessible cultural heritage and is a real challenge for the researches in the field of wider fruition.

The research is entitled "Accessible Pompeii: a study of the accessibility to Pompeii archeological site through the entrance of the Suburban Thermal Baths and the connection with the Antiquarium" and it connects with the previous research "Accessible Pompeii. Guidelines for a wider fruition of the archeological site". The latter was conducted by the "Federico II" University, under the guidance of Renata Picone, between 2011 and 2018 and focused on defining the strategies of valorization and improved fruition of the area between the space of the Pompeian res publica and this particular area was very important within the Insula Occidentalis and the entire archeological city (Ussani, 2005).

The location outside the walls and the proximity to the modern Pompeii make this architectural heritage very difficult to border. However, it could become a point of first information for the visitors entering the ancient Pompeii.

The project for a new entrance and the Superintendence offices, the Circumvesuviana railroad line, the proximity to Villa dei Misteri and to a new high-speed train station are assets to enhance the area after years in state of neglect (Picone, 2014). The Thermal Baths are involved in a wider touristic path, within the Insula Occidentalis. This path was identified in previous studies and could solve the present problems. In fact, it could allow the access to Villa Diomede and the Casa del Bracciale D'Oro thanks to new pavements, regularization of the slopes, new walkways and an elevator.

However, it is desirable the definition of a new path, that starting from the ticket office of Porta Marina (Figure 6), and running along the current Superintendence offices, could avoid the terraces, located between the entrance and the ancient Baths. Using a back entrance to the thermal complex and making the touristic paths a little longer, many differences in height could be avoided. In addition, the walk would be surrounded by greenery.

This path would allow to arrive near the Thermal Baths and a section of hammered earth could lead the visitors to a new walkway, able to enlarge the fruition of the ancient thermal complex. The new technological system, created following the principles of the critical-conservative restoration, could trace the ancient viability of the site and, at the same time, could incorporate the information, lighting, projection and sound diffusion systems for a new and wider perception of the historical and archeological heritage of the manufact.

The naturalistic path and the walkway could make the Thermal Baths accessible, making them communicate with the broadening context. The new green line connects with the long touristic walk of the Insula Occidentalis. At North, the visitors can start this 
path following the walk downstream of the Bourbonic pile towards villa di Diomede or proceeding towards Casa del Briacciale d'oro, using via dei Sepolcri to go back to the Insula. At South, the suspended walkway could solve the difference of height between via Marina and the Thermal Baths courtyard. This new configuration could be supported by an in-floor crossing that could override the abrupt via Marina and could lead to a technological system of ups and downs, made to connect the Thermal Baths with the Antiquarium. The porch underneath the Antiquarium can be used to reach the near elevator, useful to rise towards the Foro. Realizing these design indications, would allow the people with physical disabilities to visit the Thermal Baths and the surrounding landscape (Figures 7, 8 and 9).

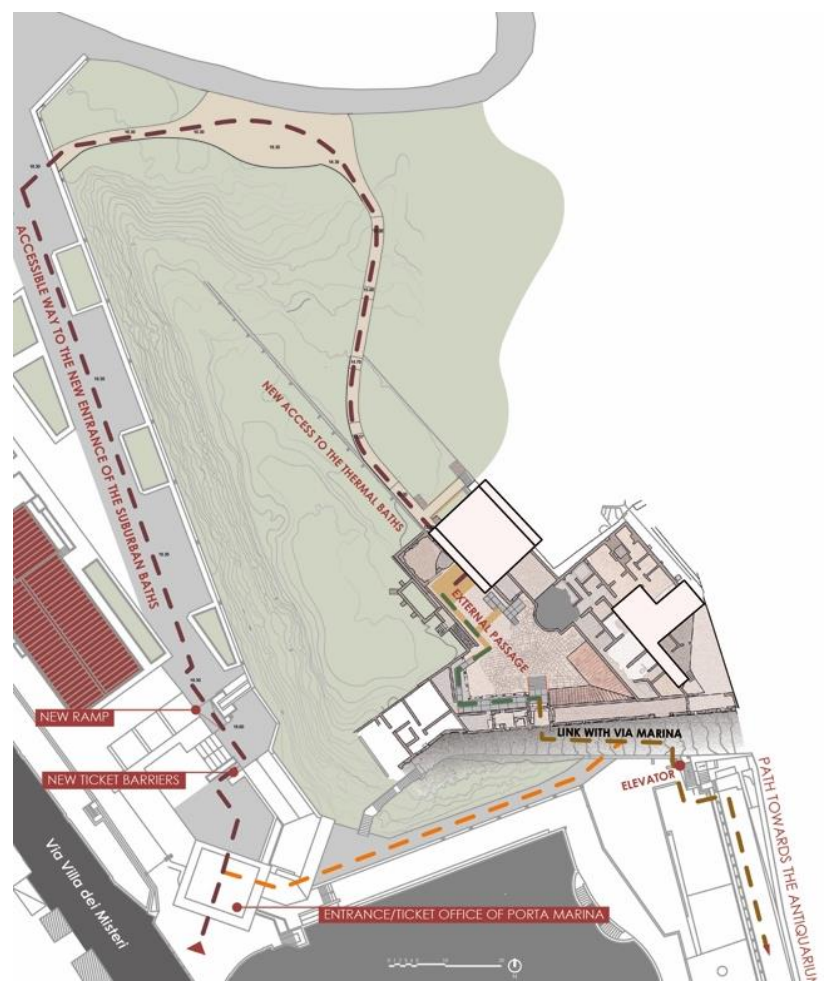

Figure 6. Design choices to make the Thermal Baths accessible: new entrance, new accessible itinerary for a wider fruition of the roman thermal complex, new connection with the Antiquarium. (Designed by L. Cappelli).

\section{INNOVATIVE STRATEGIES OF CONSERVATION AND DIGITAL HUMANITIES FOR THE SUBURBAN BATHS}

The Pompeian Thermal Baths are a very peculiar and characteristic archeological evidence, that requires a conscious understanding of his environmental, geographical conditions and of the architectural and artistic features. The placement of multimedia stands and new ways of virtual fruition can take place only after a careful examination of the manufact. Technical aspects, environments and functions were the subjects of many studies, that followed the peculiarities of the Thermal Baths, such as the entrance vestibules, the apodyterium, the latrinae, the frigidarium, the warm natatio and cold natatio, the tepidarium (Figure 10). The succession of these rooms was carefully preserved and influenced the schedule of the thermal visit. In these rooms were some sort of devices, which made both the water and the rooms warmer; thanks to the hypocaustum the warm air circulated in some holes, placed in the pavements and along the walls and realized with suspensurae (Figure 11).
The study of the Thermal Baths required a very in-depth examination of the indirect and iconographic sources, of knowledge and of the state of conservation and the types of degradation in progress. These analyses allow us to reconstruct the evolutionary phases of the factory, the previous restorations and the entire scheme of the walls. The storytelling is entrusted to the technological devices. Showing images and flows of information, these devices recreate the original experience of a customer of the Thermal Baths. At first, the regular used to go in the locker room, then in a cold bathtub, in a moderate temperature one, in a small room for sweat baths and in a room with a hot temperature. Then, the visitor is led to the last room of the Thermal Baths, where there was a large heated swimming pool. Here the multimedia information systems show the visitors how the Romans managed to heat rooms and water tanks; the visitors are also invited to focus their attention on the frescoed surfaces and the fine decorations that enriched the rooms. The citizens of Pompeii considered their visits to the Thermal Baths a cult, a recreational activity, but also an essential help for their health. Architects, restorers, historians and informers have to cooperate to create a complete and inclusive itinerary of the Thermal Baths. To sum up, following previous studies for an improved fruition and accessibility of the site, the walk of the suburban complex of the Thermal Baths will be entirely viable. Multimedia contents, hardware and software will enrich the educational and cultural offer of the site. The cooperation between technics has allowed to elaborate features like the internal walkway, that can fit cables and audio/video playback tools, or like the new coverings, that can function as displays, or like the additional panels, where are printed QR code and direct links to additional contents. The super visioning of the architect can identify paths and resting places, giving new sense and meaning to the visit.

As mentioned above, the apodyterium was the first room of the thermal circuit. It was an actual locker room with seats and niches to store personal effects. The visitor used to start the thermal itinerary, following a precise succession of rooms: the frigidarium, characterized by a circular basin with cold water, covered by a dome and fairly illuminated; the tepidarium, a room with warm water baths; the calidarium, with hot water and steam baths. This succession of spaces and the relative technological operating systems represent the main didactic contents. Through the development of a new multi-platform mobile application (iOs / Android), available in multilingual and downloadable from the website on mobile devices, the visitors can have an evocative tour, that can recreate typical visions of the place, suggestions and characters, also through Augmented Reality content (AR) (Figure 12). Not only this product allows to enhance the archaeological site, but it also improves the system of touristic services, supporting the business connected to the sector. In particular, the Augmented Reality applications allow the visitors to experience a more conscious visit. (Figure 13). The technological devices enhance the perception of the Thermal baths artistic and architectural value. Several POIs (Point of Interest) are located within the roman complex and connected to informative audio/video materials. The app was projected so that every user can create his own profile. Basing both on their personal information, such as language or age, and their needs, the visitors can choose between different itineraries. During the itinerary, the POIs (points of interest) will be automatically recognized by the mobile devices (smartphone or tablet) which will give access to in-depth texts, audio or videos, detailed contextual information, evocations and narrations, environmental sounds, narrative voices, historical photos and archival materials, videos and bibliographical references. As an example, a POI could be placed in the Apodyterium. Not only it would highlight the value of the entire room, but it could also give value to the erotic frescoes, that embellished the roman dressing room. 

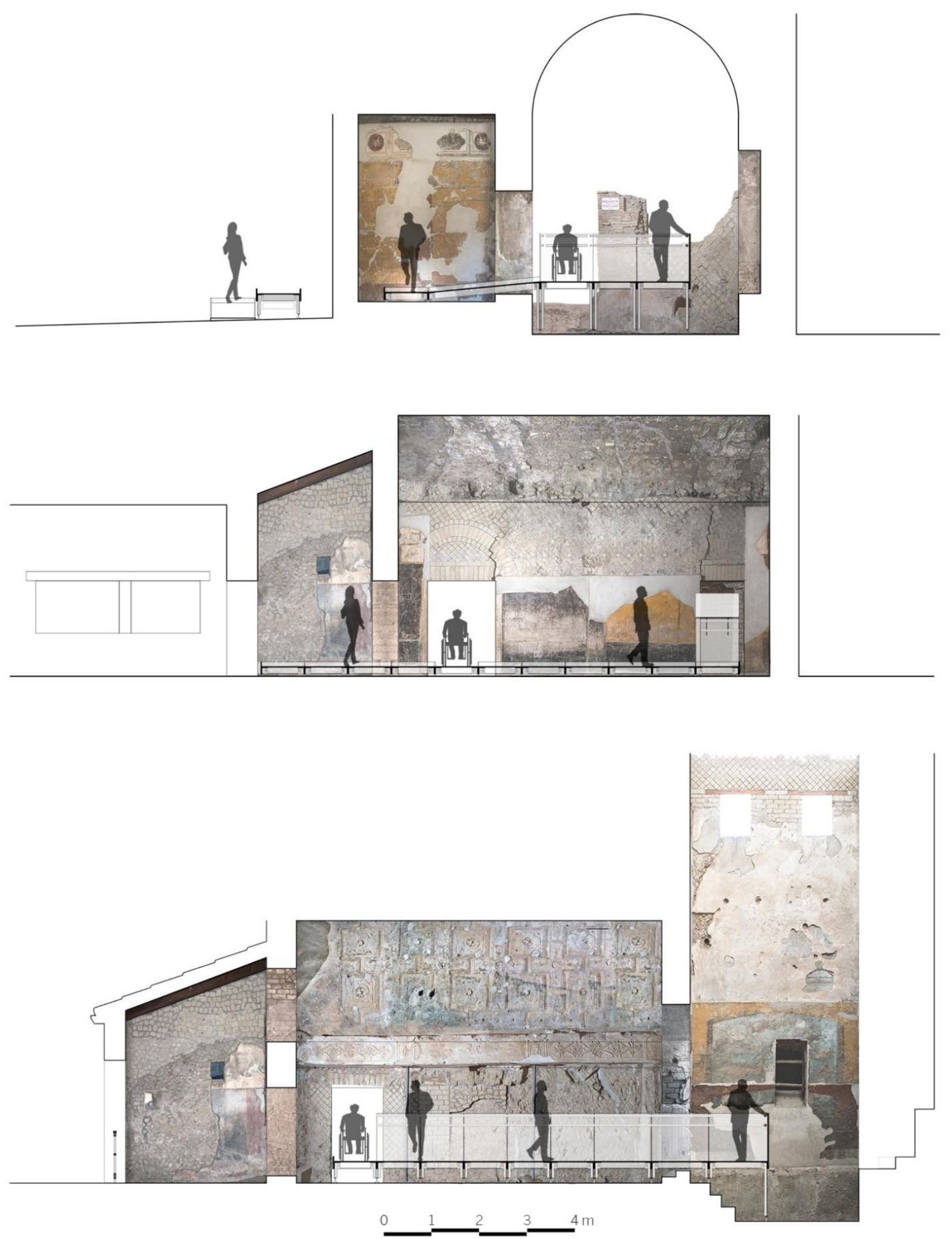

Figures 7, 8 and 9. Internal sections of the project for an improved fruition of the Suburban Thermal Baths in Pompeii, with the walkway in structural glass. From the top: natatio, apotyderium, frigidarium. (The research "Pompeii becomes accessible: a study of the accessibility to Pompeii archeological site through the entrance of the suburban Thermal Baths and the connection with the Antiquarium" was conducted by professors and scholars of the University of Naples Federico II: Renata Picone, Pasquale Miano, Paolo Giardiello, Gianpiero Lignola, Laura Bellia. Giovani studiosi: Stefano Belliazzi, Serena Borea, Luigi Cappelli, Giovanna Ceniccola; Mariapia Coccia, Ionio Conca, Sabrina Coppola, Francesca Coppolino, Giovanni Fabbrocino, Giuseppe Feola, Antonio Izzo, Antonella Lopardo, Fabiana Porreca, Giancarlo Ramaglia, Renato Rosa, Giovanna Russo Krauss, Viviana Saitto, Angela Spinelli, Antonio Stefanelli, Luigi Veronese. (Sections design by Antonio Stefanelli, 2018). 


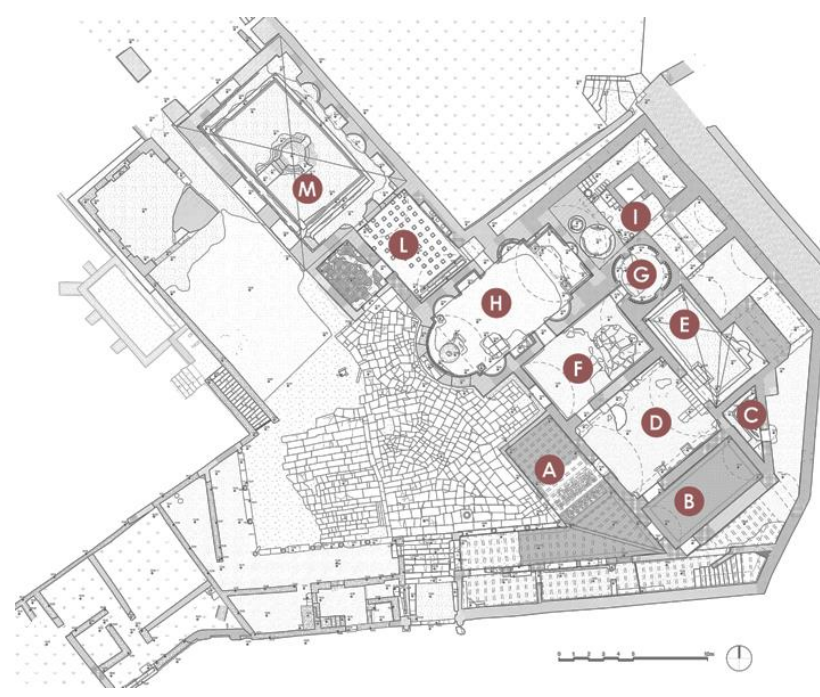

Figure 10. Planimetry of the Suburban Thermal Baths with the indication of the functions of the rooms: A. Entrance lock room, B. Apodyterium; C. Latrinae; D. Frigidarium; E. Cold Natatio; F. Tepidarium; G. Laconicum; H. Calidarium; I. Boilers; L. 'Warm' space; M. Warm Natatio. (Designed by: L. Cappelli).

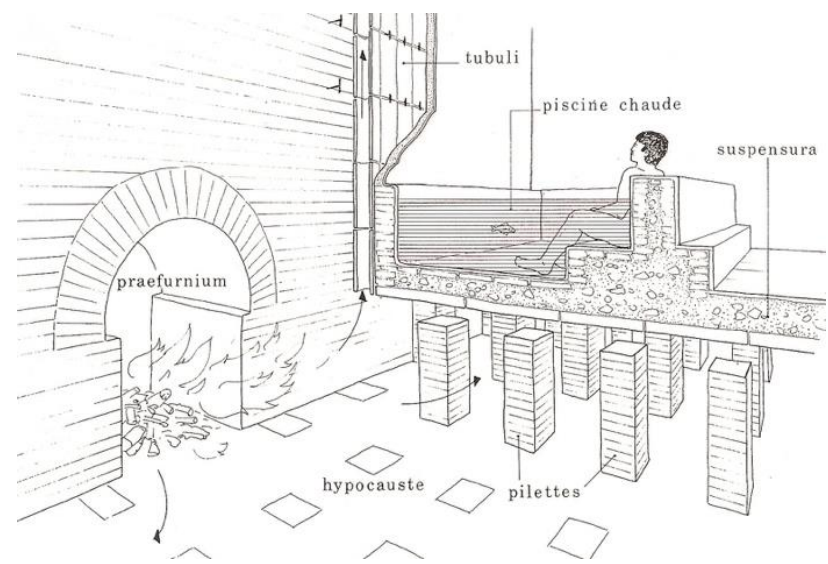

Figure 11. Functioning of the heating system of Pompeii Thermal Baths [from: Jean-Pierre Adam, La Construction romaine : matériaux et techniques, Paris, Picard, coll. « Grands manuels Picard », 1984, 1re éd., in-quarto (28 cm), 756 ill., p. 367].

Additionally, the use of lights, video projections and voices, can create a special, immersive and emotional experience during the visit. For example, the use of light design may help to bring out structural or decorative elements, which otherwise would not be noted by the visitors.

Additionally, low energy impact lights could be a useful solution to modulate the brightness of the spaces. For example, this kind of technology could be used to illuminate the mosaic of Mars, surrounded by cupids, located in the niche of the frigidarium nymphaeum (Figure 15).

The projection of video can emphasize and "animate" the paintings, whose colors faded over time, using high-brightness short-thrown projectors.

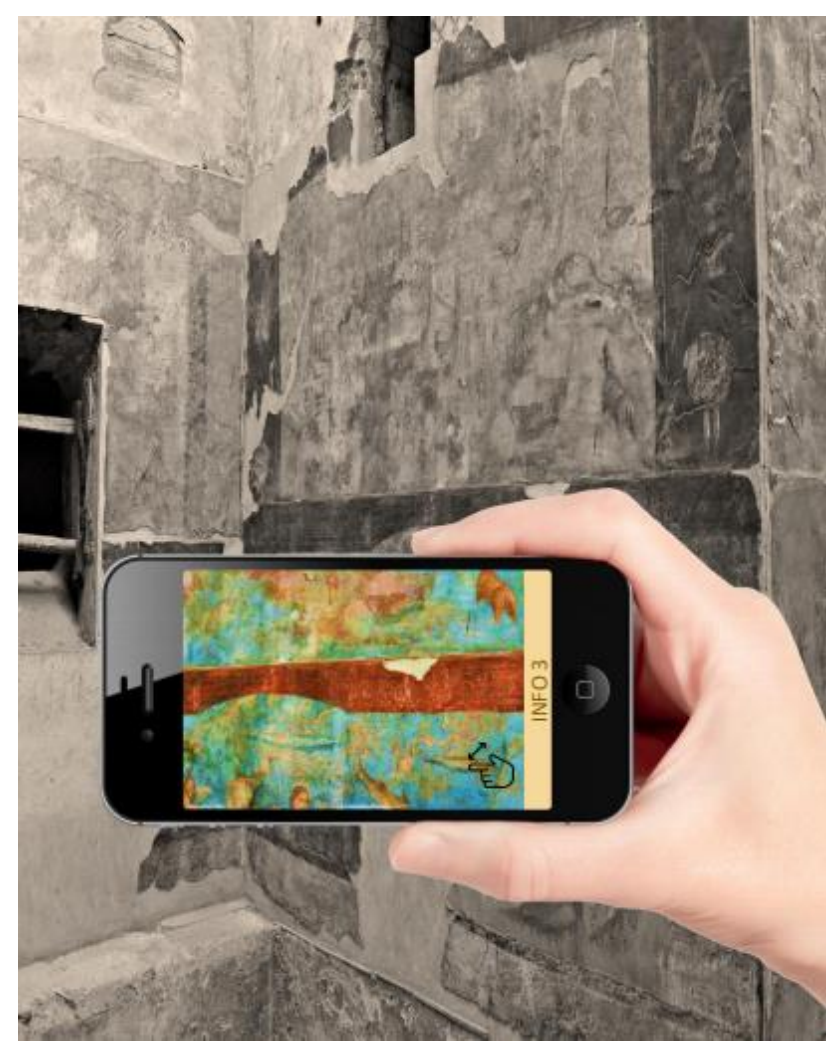

Figure 12. Example of Augmented Reality. The app can recreate the original features, allowing to compare the old and the actual perception.

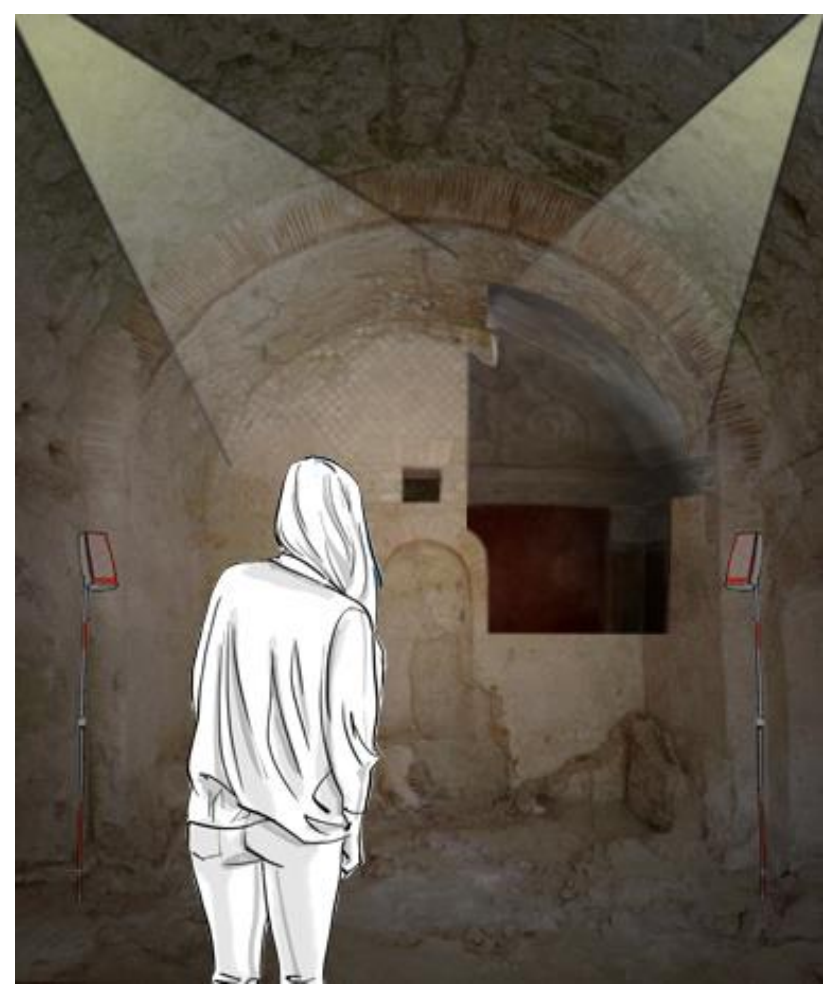

Figure 13. Example of "additioned" screening. The use of advanced technologies allowes to create visual integrations of the archelogical gaps, thanks to computer systems of Augmented Reality. 


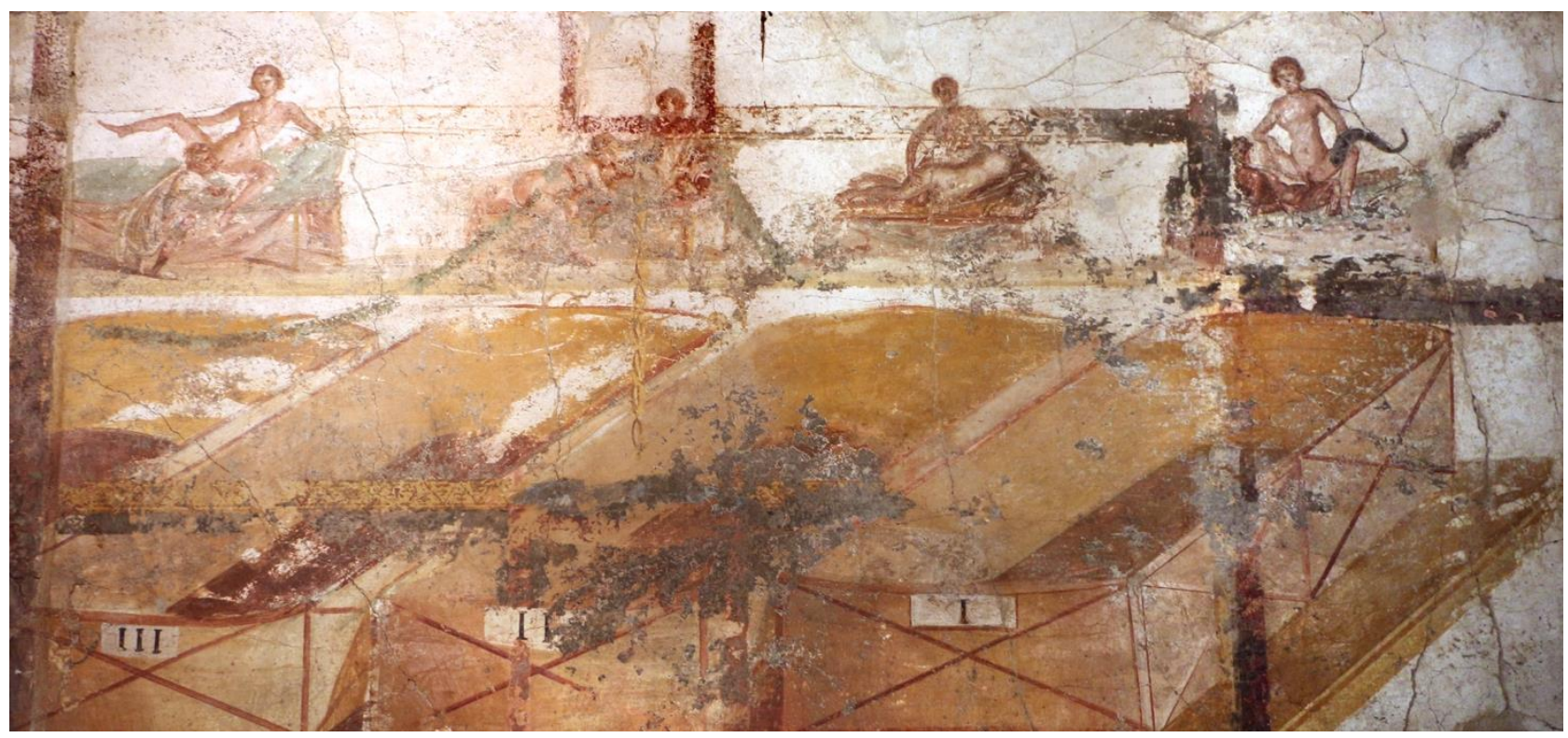

Figure 14. Erotic frescoes of the Apodyterium in the Thermal Bath.

Multimedia contents will not only be found in the internal spaces, but also outside, near the entrance of the Thermal Baths, and the access to the various rooms. POIs, placed along all the itinerary, will explain phases and techniques of construction of the complex, allowing the identification of the various elements that compose it. These POIs can be placed on special external signs and can be findable via GPS. The visitors can activate them with their smartphone, make photos, videos, read the texts available, and follow the links to the main social networks to share his experience.

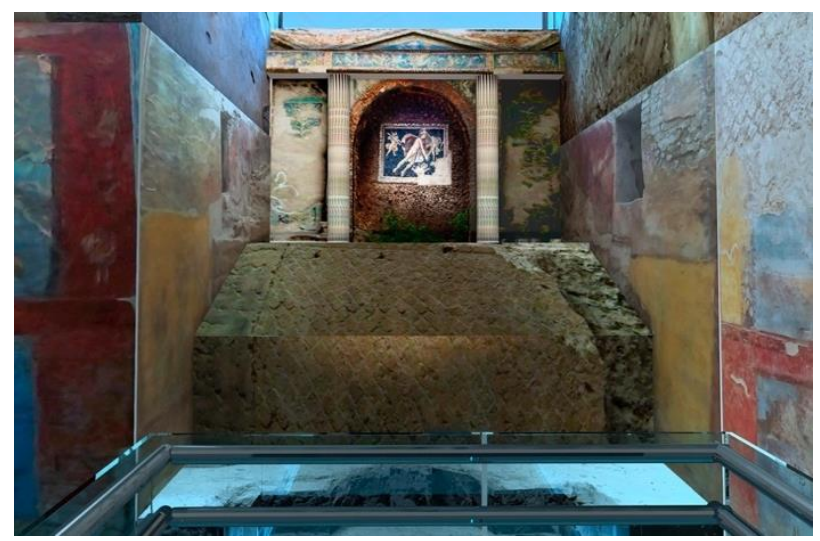

Figure 15. Lighting studies on the Ninfeo niche in the frigidarium of the Suburban Thermal Baths.

(Designed by F. Porreca).

Evidently, the relationship between the visitor and the archaeological site of the Thermal Baths is the main focus of the project. Through an immersive itinerary of the baths, the visitor can make contact with the places, the architectural construction techniques, the technologies used for the functioning of ancient systems. He can learn to recognize even the most hidden signs of material and immaterial heritage.

Being able to go from the material reality to the virtual reality, the visitor becomes the main character of his visit.

\section{REFERENCES}

Agostiniano M., Baracco L., Pane A., Vescovo F., Virdia E., 2009: Linee Guida per il superamento delle barriere architettoniche nei luoghi di interesse culturale, II edizione rivista e ampliata, Ministero per i Beni e le Attività Culturali, Roma.

Aoyagi M., Pappalardo U., 2006: Pompei Insula Occidentalis, Napoli-Tokyo.

Arenghi A., 2007: Design for all. Progettare senza barriere architettoniche, Torino, pp. 123-136.

Borea S., 2017: Il restauro delle Terme Suburbane come strategia di valorizzazione del suburbio occidentale della città archeologica di Pompei, in La Baia di Napoli. Strategie integrate per la conservazione e la fruizione del paesaggio culturale, a cura di A. Aveta, B. Gioia Marino, R. Amore, Vol. I, Paparo, Napoli, p. 287.

D'Ambrosio F., Chidimino A., Sorrentino F., 2006: Sulla termotecnica in epoca romana, in 'Atti del I Convegno Nazionale di Storia dell'Ingegneria', Cuzzolin, Napoli, p. 828.

De Simone A., 1990: Scavi e restauri a Pompei: le recenti esperienze, in «Restauro», n. 110, 1990, p. 60.

Delizia F., 2008: Dal riuso alla conoscenza dell'antico: archeologia e restauro nel XVIII secolo, in Verso una storia del restauro. Dall'età classica al primo Ottocento, a cura di S. Casiello, Alinea editrice, Firenze, p. 225-235.

Di Mauro L., 2013: La Fruizione di Pompei dal tempo del Grand Tour ai primi del Novecento, in Pompei accessibile. Per una fruizione ampliata del sito archeologico, a, cura di R. Picone, L'Erma di Bretschneider, Roma, p. 22.

Donato M., 2014: Realtà aumentata in spazi pubblici. Tecniche di base di videomapping, Le penseur.

Fiorelli G., 1875: Descrizione di Pompei, Napoli, ristampa a cura di U. Pappalardo e M. Grimaldi, Napoli 2001, p. 431. 
Grimaldi M., 2015: La Casa di Marco Fabio Rufo sulle mura dell'Insula Occidentalis Nuove scoperte e ricerche, in Pompei. La casa di Marco Fabio Rufo, Valtrend Editore, Napoli, pp. 17-22.

Iacobelli L., 1995: Le pitture erotiche delle Terme Suburbane di Pompei, L’Erma di Bretschneider, Roma, p. 18.

Jacobelli L., 1992: Le Terme Suburbane di Pompei: architettura $e$ distribuzione degli ambienti, in Roman bath and bathing. Proocedings of the First International Conference on Roman Baths, held and Baths, England, 30 marzo-4 aprile 1992, pp. $223-$ 235;

Jacobelli L., 2001: Pompei fuori le mura: note sulla gestione e l'organizzazione dello spazio pubblico e privato, in Pompei tra Sorrento e Sarno. Atti del terzo e quarto ciclo di conferenze di geologia, storia e archeologia (Pompei, gennaio 1999-maggio 2000), a cura di F. Senatore, Bardi, Roma, p. 37.

Longobardi G., 2002: Pompei sostenibile, L'Erma di Bretschneider, Roma.

Maiuri A., 1947: Pompei e la guerra, in «La Rassegna d'Italia», n. 1, gennaio 1946, pp. 134-140.

Maiuri A., 1947: Restauri di guerra a Pompei, in «Le vie d'Italia», n. 3, marzo 1947, pp. 215-221.

Maiuri A., 1950: Gli scavi di Pompei dal 1879 al 1948, in Pompeiana. Raccolta di studi per il secondo centenario degli scavi di Pompei, Gaetano Macchiaroli Editore, Napoli, pp. 2226.

Maiuri A., 1951: Gli scavi di Pompei nel programma delle opere per la Cassa per il Mezzogiorno, Ente provinciale per il turismo, Napoli.

Maiuri A., 1951: Gli scavi di Pompei nel programma delle opere per la Cassa per il Mezzogiorno, Ente provinciale per il turismo, Napoli.

Maiuri A., 1960: Pompei. Sterro dei cumuli e isolamento della cinta murale. Contributo all'urbanistica della città sepolta, estratto dal Bollettino D'Arte del Ministero della Pubblica Istruzione, 1-2.

Montani, P., 2010: L'immaginazione intermediale. Perlustrare, rifigurare, testimoniare il mondo visibile, Laterza, Roma-Bari.

Ornati A., 2000: Architettura e barriere. Storia e fatti delle barriere architettoniche in Italia e all'estero, Milano.

Osanna M, 2019: Pompeii and its second life throughout the multidisciplinary researches, Journal of Cultural Heritage, November 2019, Vol. 40, pp. 227-227.

Osanna M, Rinaldi E., 2018: Access and Conservation at Pompeii: Strategies for Sustainable Coexistence, Studies in Conservation, 1 august 2018, Vol. 63, pp. 203-208.

Osanna M., Picone. R., 2018: Restaurando Pompei: riflessioni a margine del Grande Progetto, L'Erma di Breschneider, Roma.

Pane A., 2005: Accessibilità e superamento delle barriere architettoniche negli edifici e nei siti storici: alcuni problemi ricorrenti, «Arkos», VI, 11, luglio-settembre, pp. 39-46.
Pesando F., 2004: Le terme Repubblicane di Pompei: cronologia $e$ funzione, «Annali dell'Istituto universitario orientale di Napoli», n. 9, pp. 221-241.

Picone R., 2004: Conservazione e accessibilità. Il superamento delle barriere architettoniche negli edifici storici, Napoli, pp. 1820.

Picone R., 2011: Pompei alla guerra. Danni bellici e restauri nel sito archeologico, in I ruderi e la guerra. Memoria, ricostruzioni, restauri, a cura di S. Casiello, Nardini, Firenze.

Picone R., 2013: (a cura di), Pompei Accessibile, per una fruizione ampliata del sito archeologico, L'Erma di Bretschneider, Roma.

Picone R., 2014: Giorgio Rosi: restauro e tutela del paesaggio (1936-1964), in Ananke, Milano settembre 2014

Picone R., Spinosa A., Vitagliano G., 2011: Wide Accessibility and Conservation of Architectural Heritage: problems and methodological guidelines, in ENHSA-EAAE Conservation Network workshop on Conservation/ Transformation (Dublin, Ireland 17-19 September 2009), Leuven, Belgique.

Tomasi F., 2008: Metodologie informatiche e discipline umanistiche, Roma, Carocci.

Ussani V.S., 2005: Moregine: suburbio portuale di Pompei, Loffredo Editore, Napoli.

Wertsch J. V., 1998: Mind as action, Oxford University Press. 